\title{
The diversity of edible plants traded in Ir. Soekarno Market, a traditional market in Sukoharjo District, Indonesia
}

\author{
AVYDA KOZA DEANOVA ${ }^{1}$, CELIN MAYLANI PRISTIAWATI ${ }^{1}$, DEWI APRILIA ${ }^{\mathbf{1}}$, IVO SOLIKAH ${ }^{1}$, \\ MARHCELINA NURCAHYATI ${ }^{1}$, NOR LIZA ${ }^{2}$, WHIDI HIMAWAN ${ }^{1,3}$, RUHYAT PARTASASMITA $^{4, *}$, \\ AHMAD DWI SETYAWAN ${ }^{1,5}$ \\ ${ }^{1}$ Department of Environmental Science, Faculty of Mathematics and Natural Sciences, Universitas Sebelas Maret. J1. Jend. Urip Sumoharjo No. 179, \\ Surakarta 57128, Central Java, Indonesia.Tel.: +62-271-663375, `email: volatileoils@ gmail.com \\ ${ }^{2}$ Biodiversity Study Club, Department of Biology, Faculty of Mathematics and Natural Sciences, Universitas Sebelas Maret. Jl. Ir. Sutami No. 36A, \\ Surakarta 57126, Central Java, Indonesia \\ ${ }^{3}$ Environmental Science Research Group, Universitas Sebelas Maret. Jl. Ir. Sutami No. 36A, Surakarta 57126, Central Java, Indonesia \\ ${ }^{4}$ Department of Biology, Faculty of Mathematics and Natural Sciences, Universitas Padjadjaran. J1. Raya Bandung-Sumedang Km 21, Jatinangor, \\ Sumedang 45363, West Java, Indonesia. "pass away \\ ${ }^{5}$ Biodiversity Research Group, Universitas Sebelas Maret. J1. Ir. Sutami No. 36A, Surakarta 57126, Central Java, Indonesia
}

Manuscript received: 26 January 2021. Revision accepted: 31 August 2021.

\begin{abstract}
Deanova AK, Pristiawati CM, Aprilia D, Solikah I, Nurcahyati M, Liza N, Himawan W, Partasasmita R, Setyawan AD. 2021. The diversity of edible plants traded in Ir. Soekarno Market, a traditional market in Sukoharjo District, Indonesia. Biodiversitas 22: 4095-4105. Market is one of the most important economic sectors in a country. One type of market is a traditional market that is synonymous with squalid, overcrowded and slum conditions. However, traditional markets provide essential commodities that are relatively cheaper and fresher than modern markets. The purpose of this research was to record the diversity of species and varieties of edible plants traded in Ir. Soekarno Market, a traditional market in Sukoharjo District. Plant commodities observed were vegetables, spices, fruits, and staples sold by the sellers in this market. The method used in this research was qualitative based on the ethnobotany approach. Meanwhile, to collect primary data, several field techniques were used, namely direct observation such as market commodity surveys, trader observations, and trader interviews. The direct survey results showed that the edible plant commodities consisted of 105 plant species representing 28 families. The variations found included 9 types of rice, 4 types of onions, 7 types of bananas, and 9 types of beans. The decline in the number of traded commodities and the lack of visitors was due to the increase in COVID-19 cases in Sukoharjo and disputes between traders and local government. Thus until recently, Ir. Soekarno Market, which was originally the main market full of visitors, became a market that was empty of visitors and traders.
\end{abstract}

Keywords: Biodiversity conservation, food diversification, food security

\section{INTRODUCTION}

Economy is the most important sector in a country and can also be a reference for making decisions. One of the important economic sectors is the market (Aminursita and Abdullah 2018). A market is a place where there are transactions between buyers and sellers to exchange goods and services due to demand and supply (Indrawati and Yovita 2014). The market mechanism brings together the two parties to make transactions both in the form of services and goods in the form of production and price determination (Aliyah 2017).

The market is divided into two types, namely traditional and modern markets. Modern markets sell goods at fixed prices and with self-service systems, for example, supermarkets and malls (Arianty 2013). Meanwhile, a traditional market is a place that brings together buyers and sellers in which direct transactions and bargaining occurs (Malano 2011; Syarifuddin 2018). Traditional markets are usually synonymous with squalid, crowded, slum conditions. and manipulation by traders (Arianty 2013). Without revitalization and improvement, the traditional market might experience a declining number of visitors, which leads to shifting consumer preference to the modern one, such as supermarket and online shopping (Jeong and Ban 2020; Septiari and Kusuma 2016). This worrisome fact can cause depletion of traditional markets in the future, though many people depend much on it such as farmers that sell their products only to local resellers (Sahban and Perwira 2018; Susilowati 2014).

However, current presence of modern markets is more desirable than traditional markets because modern markets provide convenience, so customers tend to shop there and are reluctant to shop in traditional markets (Rusham 2016). However, traditional markets have more advantages than modern markets, such as direct transactions and bargaining, relatively affordable prices, goods sold completely, and food that does not contain preservatives (Susanto 2018). In addition, the sellers in the traditional market remember the customer's name, resulting in visitors' satisfaction, which makes them return to the traditional market in the future (Rahadi 2011; Suhud et al. 2019). Interactions within local markets can improve relationships between people and neighborhoods and strengthen the sense of belonging in a community (Agboola et al. 2018). These emotional bindings can be found more in local markets than in modern ones 
that use self-service approach (Lima-Filho et al. 2009).

Diversity and availability of goods in traditional markets are high (Ela et al. 2016), in the forms of dry food, wet food products, and industrial products. In traditional markets, there are also agricultural commodities such as staple food, including rice (Yurlisa et al. 2017). Traditional markets have various local potentials that are used by residents to market agricultural products, namely vegetables and plantation crops (Kharisma 2014). Traditional markets usually promote fresher vegetable commodities as they are supplied directly from local farmers. However, the modern ways are more effective and efficient in distributing vegetables to consumers than the traditional methods (Cadilhon et al. 2006).

One of the traditional markets in Indonesia is Ir. Soekarno Market, located in Sukoharjo District, Central Java Province, Indonesia. This study aimed to determine the diversity of plant species and their variations traded in Ir. Soekarno Market.

\section{MATERIALS AND METHODS}

\section{Study locations}

This research was conducted in Ir. Soekarno Market, a traditional market, situated in the capital town of Sukoharjo, Sukoharjo District, Central Java, Indonesia (Figures 1 and 2) from November to December 2020 in the COVID-19 pandemic period where community activities are limited. This market is located in Jendral Sudirman Street. It is approximately $12.3 \mathrm{~km}$ south of Surakarta city center and quite reachable using private and public transportation, including city buses, and local minibusses (angkot). Ir. Soekarno Market opens on the weekdays from Monday to Friday between 01.00 am to $17.00 \mathrm{pm}$, divided into two 2 shifts. The morning market opens from $01.00 \mathrm{am}$ to 07.00 am and the afternoon market from 08.00 am to $17.00 \mathrm{pm}$ (Majiid et al. 2020). Various plants are traded in this market (Figure 3).

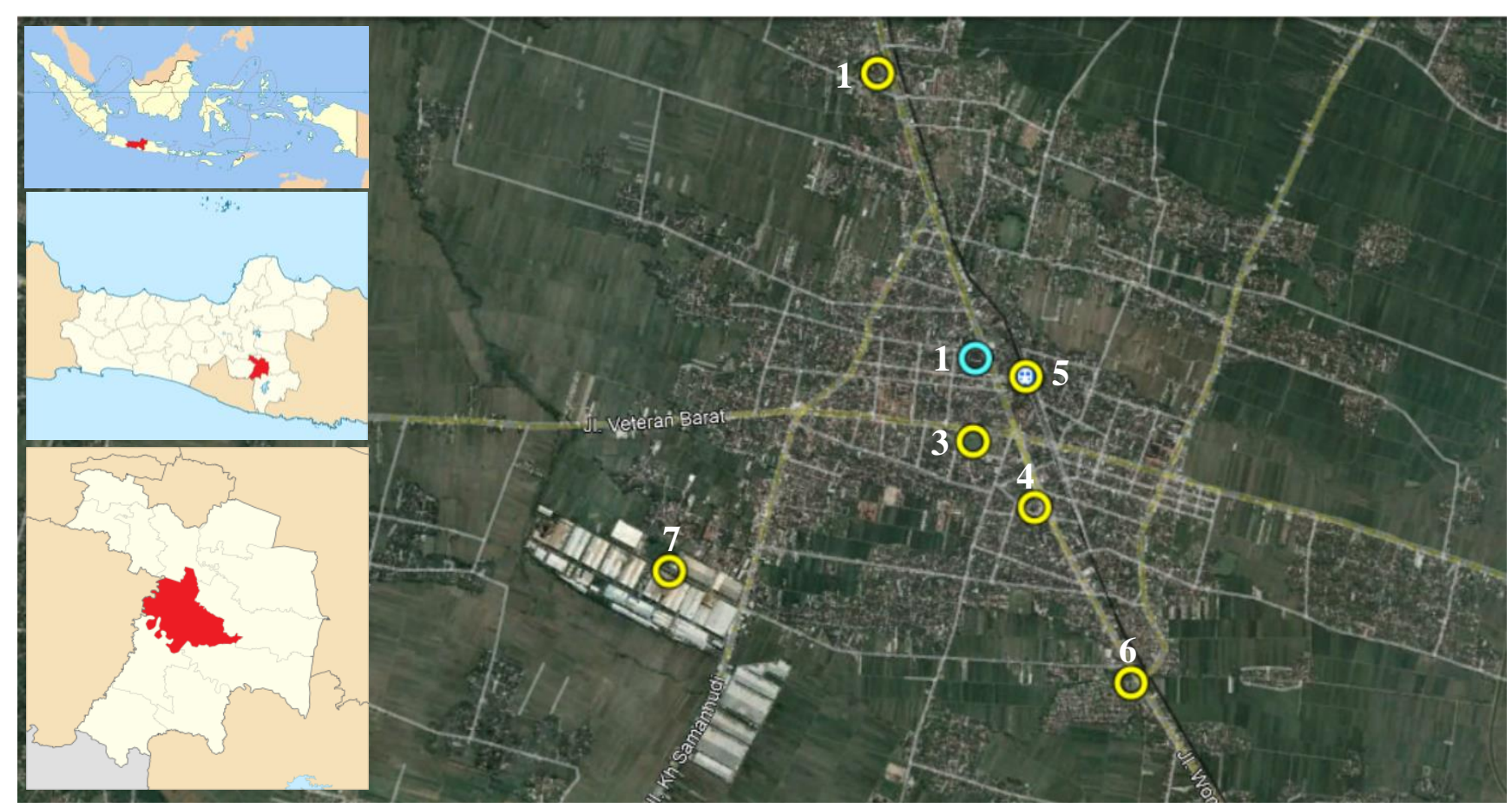

Figure 1. Research location situated in the Ir. Soekarno Market, Sukoharjo District, Central Java Province, Indonesia. Note: 1. The market, 2. District office, 3. Public plaza (alun-alun), 4. Great masjid (Masjid Agung), 5. Train station, 6. Bus terminal, 7. Industrial area. The rest area is dominated by housing and sawahs (rice fields).

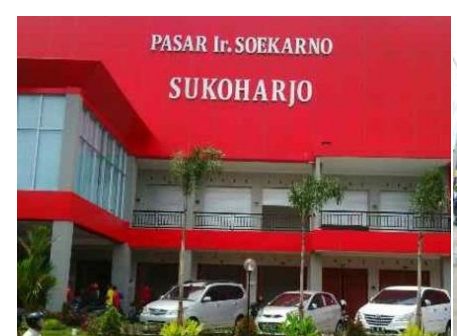

A

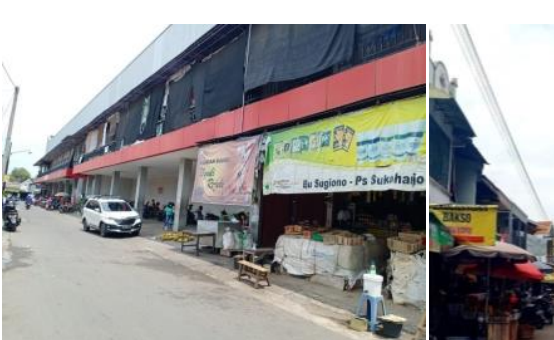

B

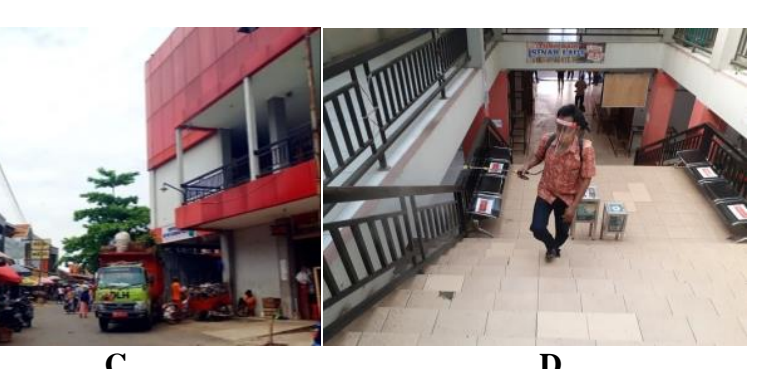

C
D

Figure 2. The Ir. Soekarno Market Building, Sukoharjo District, Central Java Province, Indonesia. A. Front view, B. Back view, C. Side view, D. Inside view 


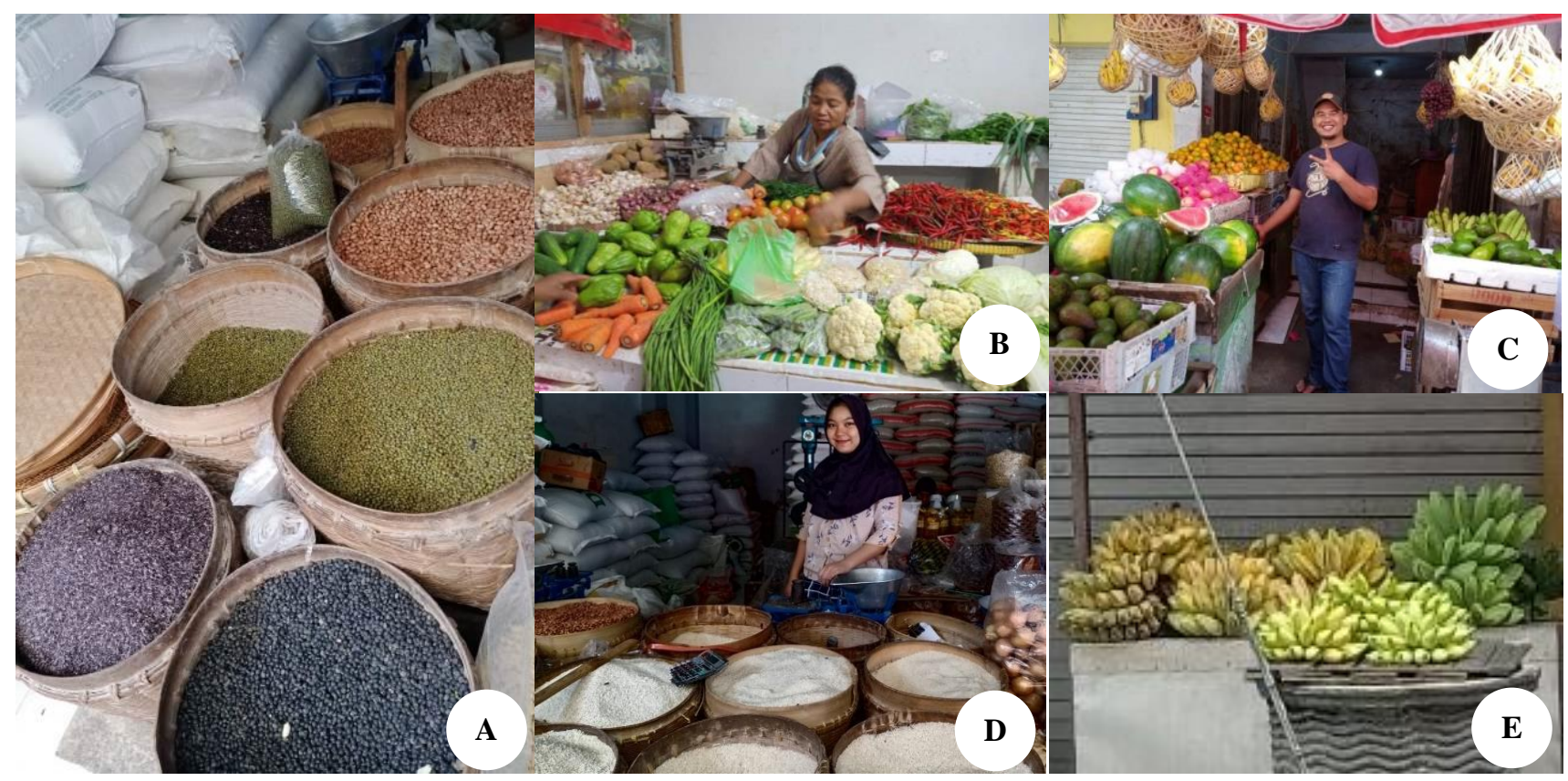

Figure 3. Plants commodities traded in Ir. Soekarno Market, Sukoharjo, Indonesia. A. Various legumes, B. Various vegetables, C. Various fruits, D. Rice varieties, E. Banana varieties

Ir. Soekarno Market is the largest traditional market in Sukoharjo District with a total area of approximately $6,353.44 \mathrm{~m}^{2}$. The area of this traditional market consists of 400 stalls divided into two areas, namely the inner and outer areas. However, many kiosks have been forced to close due to the Covid-19 pandemic. The standard size of the kiosk in this market is about $2 \times 3 \mathrm{~m}$. The outside is used as a parking area for the customers and traders. This market is also equipped with public facilities, such as a vast parking site for traders and visitors, restrooms, and security posts (Majiid et al. 2020; Ar Rosyidi et al. 2016).

Mostly, sellers have their own kiosk and place the commodities on a table. This market provides various daily needs, such as foods (vegetables, spices, fish, meat, market snacks, traditional drinks (jamu), household appliances, and clothes. The food traders often bring a stove and other cooking utensils to process the customer's orders on-site. However, the rest of sellers tend to trade their products outside the kiosks provided, such as on pedestrian sites. The accessibility is the main reason why they refuse to sell in kiosks as their current sites are more reachable for visitors (Aprilianawati et al. 2018). This is also due to revitalization of Ir. Soekarno Market in 2014 caused conflict between traders and the authorities. Aprilianawati (2018) mentioned in her study based on data from the Department of Trade of Sukoharjo District, that there were more than 900 traders who rented the kiosks before revitalization, but the number decreased to only about 600 stalls after the revitalization.

\section{Research procedure}

This research used a qualitative descriptive method, where the data were collected in the form of observation tables and pictures with an ethnobotany approach (Iskandar et al. 2018). Observation, interviews, and documentation were conducted to obtain primary data, namely food commodities that are widely traded, and variations in edible species that are traded in the market. In-depth interviews were done with 30 respondents chosen randomly, consisting of traders (24), consumers (4), and market management (2).

\section{Data analysis}

The primary data were classified based on its family, edible portion, and commodity categories, including carbohydrate staple foods including potatoes, vegetables, fruits and spices, and then analyzed descriptively. Plant species were identified using a variety of online source (http://www.plantsoftheworldonline.org/), books (Backer and Bakhuizen van den Brink 1963, 1965, 1968) and botanical standards (Verheij and Coronel 1991; Lemmens et al. 1991, 2003; Siemonsma and Piluek 1991; Grubben and Partohardjono 1996; de Guzman and Siemonsma 1999; de Padua et al. 1999; van der Vossen and Umali 2001; van Valkenburg and Bunyapraphatsara 2002). In addition, reference studies were also carried out from field observations through references to journals, books, proceedings, and others to support the data needed and refer to research conducted by (Iskandar et al. 2018).

\section{RESULTS AND DISCUSSION}

\section{History of Ir. Soekarno Market}

Ir. Soekarno Market in Sukoharjo is the largest traditional markets in Sukoharjo District. This district was originally part of Kawedanan Larangan, and then in 1874 it was turned to Sukoharjo District by Sunan Pakubuwono 
IX, king of Surakarta, a kingdom under Nederland Indies influence. According to history, this district is experiencing continuous development. With population growth and over time, there have been protection efforts by the local government to increase the competitiveness of traditional markets. One of the efforts made was market revitalization. For that reason, the cornerstone for rebuilding was laid on June 8, 2012. This market was previously named Sukoharjo Market, then, the name turned into Ir. Soekarno Market after revitalization (Ar Rosyidi et al. 2016).

This market is called Ir. Soekarno Market to appreciate the struggle of Indonesian hero, i.e., the Indonesian independence proclaimer (Soekarno) and to continue $\mathrm{Mr}$. Soekarno's ambition for community welfare and make Indonesia an independent nation. The market improvement was carried out to provide extended space for trader kiosks $2 \times 3$ meters square in size with approximately 400 stalls, spread in two floors of the market. To increase the competitiveness of traditional markets in this developing community, the commodities sold in this market have been increased and varied goods selling, ranging from vegetables, spices, fish, meat, local snacks (jajan pasar), traditional drinks, groceries and household tools such as electronics, as well as services such as bank, barber and beauty salon, restaurants, etc. (Majiid et al. 2020).

This revitalization of this market was done in order to improve the service quality. The considerable improvements such as adding the number of officers, improving the public facilities, and improving the cleanliness of the market have been conducted to attract more customers (Ar Rosyidi et al. 2016).

\section{Species diversity and variation}

There were 105 species or its varieties of plants from 28 families traded in Ir. Soekarno Market, divided into several commodities. Most plants traded belong to the families Fabaceae, Poaceae, Solanaceae and Zingiberaceae, while Amaranthaceae, Asteraceae, Bromeliaceae, Cactaceae, Caricaceae, Moraceae, Myristicaceae, Pandanaceae, Vitaceae made up the least proportion, only represented by one species each (Table 1, Figure 3). These commodities were then divided into four categories: vegetables, fruits, herb and spices, and staple foods (Figure 4).

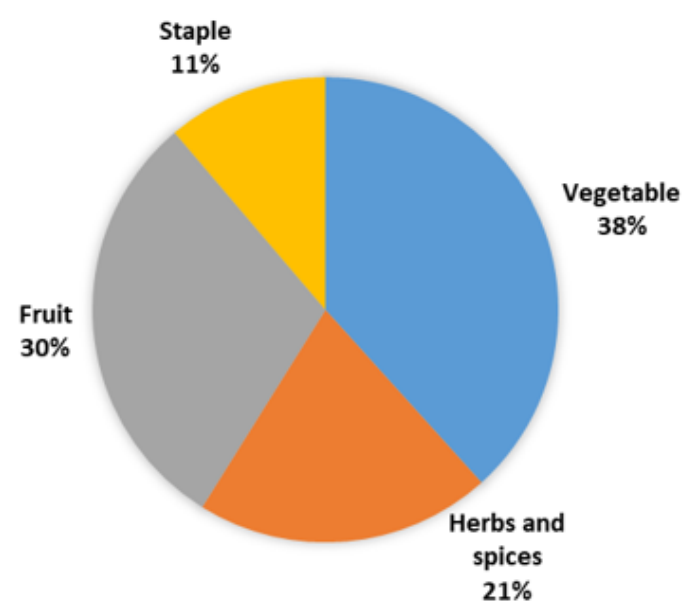

Figure 4. Categories of food plants traded in Ir. Soekarno Market, Sukoharjo, Indonesia

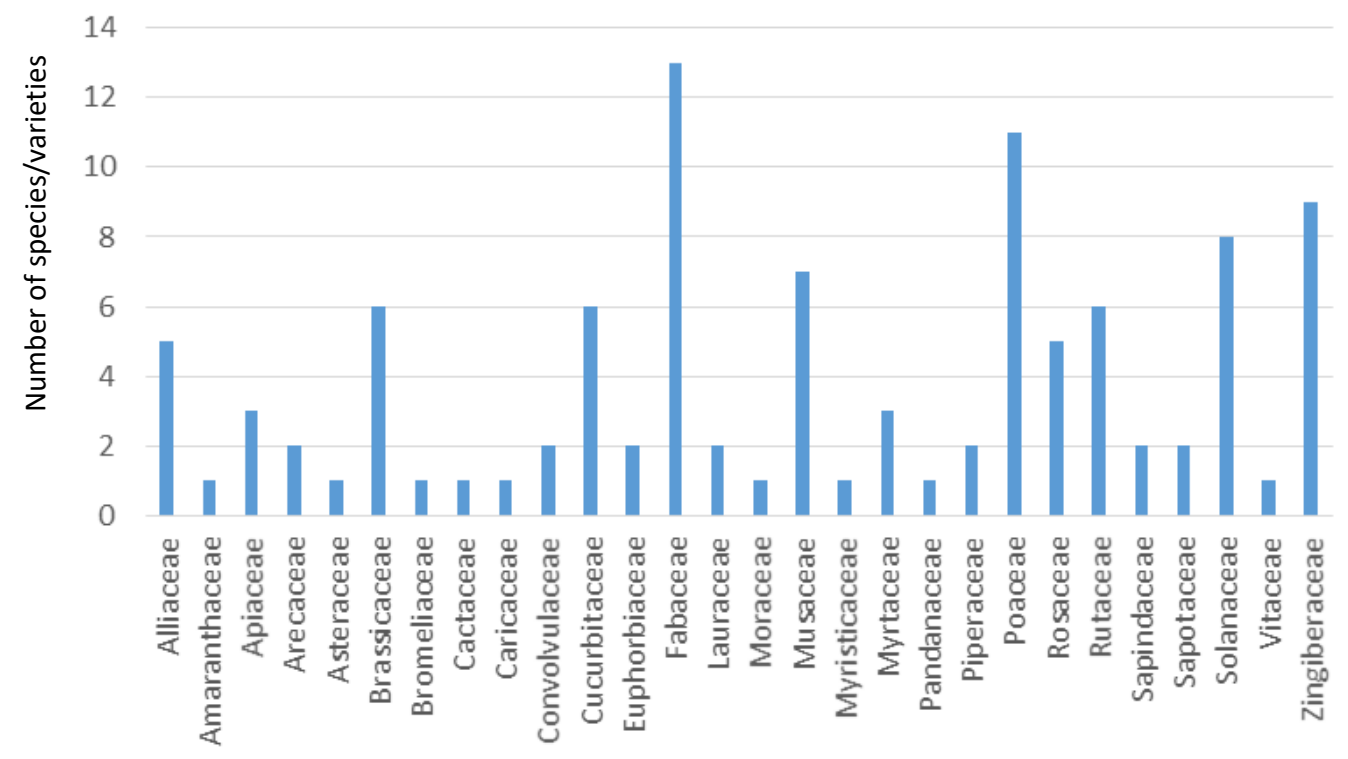

Figure 3. Family groups of food plants traded in Ir. Soekarno Market, Sukoharjo, Indonesia 
Table 1. List of food plant commodities that are widely traded in Ir. Soekarno Market, Sukoharjo, Indonesia

\begin{tabular}{|c|c|c|c|c|c|}
\hline Common name & Local name & Family & Scientific name & Category & $\begin{array}{l}\text { The part } \\
\text { used }\end{array}$ \\
\hline Onion & Bawang bombay & Alliaceae & Allium cepa L. var. cepa L. & Vegetable & Bulbs \\
\hline Shallot & Bawang merah & Alliaceae & Allium cepa var. aggregatum G.Don & Vegetable & Bulbs \\
\hline Garlic & Bawang putih & Alliaceae & Allium sativum $\mathrm{L}$. & Vegetable & Bulbs \\
\hline Leek & Bawang prei & Alliaceae & Allium ampeloprasum $\mathrm{L}$. & Vegetable & Leaf \\
\hline Spring onion & Bawang daun & Alliaceae & Allium fistulosum $\mathrm{L}$. & Vegetable & Leaf \\
\hline Spinach & Bayam & Amaranthaceae & Amaranthus hybridus L. & Vegetable & Leaf \\
\hline Celery leaves & Seledri & Apiaceae & Apium graveolens $\mathrm{L}$. & Vegetable & Leaf \\
\hline Coriander & Ketumbar & Apiaceae & Coriandrum sativum $\mathrm{L}$. & Herbs-spices & Fruit \\
\hline Carrot & Wortel & Apiaceae & Daucus carota $\mathrm{L}$. & Vegetable & Tubers \\
\hline Snakefruit & Salak & Arecaceae & Salacca zalacca (Gaertn.) Voss & Fruit & Fruit \\
\hline Coconut & Kelapa & Arecaceae & Cocos nucifera $\mathrm{L}$ & Fruit & Fruit \\
\hline Wild cosmos & Kenikir & Asteraceae & Cosmos caudatus Kunth & Vegetable & Leaf \\
\hline Broccoli & Brokoli & Brassicaceae & Brassica oleracea var. italic Plenck & Vegetable & Leaf \\
\hline Cauliflower & Kembang kol & Brassicaceae & Brassica oleracea var. botrytis L. & Vegetable & Leaf \\
\hline Cabbage & Kubis & Brassicaceae & Brassica oleracea var. capitata $\mathrm{L}$. & Vegetable & Leaf \\
\hline Mustard & Sawi & Brassicaceae & Brassica juncea (L.) Czern & Vegetable & Leaf \\
\hline Lettuce & Selada & Brassicaceae & Lactuca sativa $\mathrm{L}$. & Vegetable & Leaf \\
\hline Kale & Kale & Brassicaceae & Brassica oleracea var. sabellica $\mathrm{L}$. & Vegetable & Leaf \\
\hline Pineapple & Nanas & Bromeliaceae & Ananas comosus (L.) Merr. & Fruit & Fruit \\
\hline Dragon fruit & Buah naga & Cactaceae & $\begin{array}{l}\text { Hylocereus costaricensis (F.A.C.Weber) } \\
\text { Britton \& Rose }\end{array}$ & Fruit & Fruit \\
\hline Papaya & Pepaya & Caricaceae & Carica papaya $\mathrm{L}$ & Fruit & Fruit \\
\hline Sweet potato & Ubi jalar & Convolvulaceae & Ipomoea batatas (L.) Lam. & Staple & Tubers \\
\hline Water spinach & Kangkung & Convolvulaceae & Ipomoea aquatica Forssk & Vegetable & Leaf \\
\hline Pumpkin & Labu & Cucurbitaceae & Cucurbita maxima Duchesne & Vegetable & Fruit \\
\hline Chayote & Labu siam & Cucurbitaceae & Sechium edule (Jacq.) Sw. & Vegetable & Fruit \\
\hline Melon & Melon & Cucurbitaceae & Cucumis melo $\mathrm{L}$. & Fruit & Fruit \\
\hline Cucumber & Mentimun & Cucurbitaceae & Cucumis sativus L. & Vegetable & Fruit \\
\hline Bitter melon & Pare & Cucurbitaceae & Momordica charantia $\mathrm{L}$. & Vegetable & Fruit \\
\hline Watermelon & Semangka & Cucurbitaceae & Citrullus lanatus (Thunb.) Matsum. \& Nakai & Fruit & Fruit \\
\hline Candlenut & Kemiri & Euphorbiaceae & Aleurites moluccanus (L.) Wild. & Herbs-spices & Fruit \\
\hline Cassava & Singkong & Euphorbiaceae & Manihot esculenta Crantz & Staple & Tubers \\
\hline Bean & Buncis & Fabaceae & Phaseolus vulgaris $\mathrm{L}$. & Vegetable & Leaf \\
\hline Jengkol & Jengkol & Fabaceae & $\begin{array}{l}\text { Archidendron pauciflorum (Benth) } \\
\text { I.C.Nielsen }\end{array}$ & Vegetable & Fruit \\
\hline Mungbean & Kacang hijau & Fabaceae & Vigna radiata $($ L.) R.Wilczek & Vegetable & Fruit \\
\hline Pea & Kacang kapri & Fabaceae & Pisum sativum $\mathrm{L}$. & Vegetable & Fruit \\
\hline Pea & Kacang ercis & Fabaceae & Pisum sativum $\mathrm{L}$. & Vegetable & Fruit \\
\hline Soya bean & Kacang kedelai & Fabaceae & Glycine $\max$ L. Merr & Vegetable & Fruit \\
\hline Edamame & Edamame & Fabaceae & Glycine $\max$ L. Merr & Vegetable & Fruit \\
\hline Cashew nut & Jambu monyet & Fabaceae & Anacardium occidentale L. & Vegetable & Fruit \\
\hline Long bean & Kacang panjang & Fabaceae & Vigna unguiculata (L.) Walp. & Vegetable & Fruit \\
\hline Peanut & Kacang tanah & Fabaceae & Arachis hypogaea $\mathrm{L}$. & Vegetables, spices & Seed \\
\hline Sappan wood & Secang & Fabaceae & Caesalpinia sappan $\mathrm{L}$. & Herbs-spices & Bark \\
\hline Sprouts & Kecambah & Fabaceae & Not identified & Vegetable & Bark \\
\hline Stink bean & Petai & Fabaceae & Parkia speciosa Hassk. & Vegetable & Fruit \\
\hline Avocado & Alpukat & Lauraceae & Persea americana Mill. & Fruit & Fruit \\
\hline Cinnamon & Kayu manis & Lauraceae & Cinnamomum verum J.Presl & Herbs-spices & Bark \\
\hline Jackfruit & Nangka & Moraceae & Artocarpus heterophyllus Lam. & Fruit & Fruit \\
\hline Cavendish & Pisang ambon & Musaceae & Musa X sapientum $\mathrm{L}$. & Fruit & Fruit \\
\hline Kapas banana & Pisang kapas & Musaceae & Musa X paradisiaca $\mathrm{L}$. & Fruit & Fruit \\
\hline Kepok banana & Pisang kepok & Musaceae & Musa acuminata $X$ balbisiana $\mathrm{L}$. & Fruit & Fruit \\
\hline Mas banana & Pisang mas & Musaceae & Musa X paradisiaca L. & Fruit & Fruit \\
\hline Plantain & Pisang raja & Musaceae & Musa X paradisiaca L. & Fruit & Fruit \\
\hline Susu banana & Pisang susu & Musaceae & Musa acuminata "lady finger" & Fruit & Fruit \\
\hline Uli banana & Pisang uli & Musaceae & Musa X paradisiaca $\mathrm{L}$. & Fruit & Fruit \\
\hline Nutmeg & Pala & Myristicaceae & Myristica fragrans Houtt. & Herbs-spices & Seed \\
\hline Clove & Cengkeh & Myrtaceae & $\begin{array}{l}\text { Syzygium aromaticum (L.) Merr. \& } \\
\text { L.M.Perry }\end{array}$ & Herbs-spices & Fruit \\
\hline Guava & Jambu biji & Myrtaceae & Psidium guajava L. & Fruit & Fruit \\
\hline Bay leaf & Salam & Myrtaceae & Syzygium polyanthum (Wight) Walp. & Herbs-spices & Leaf \\
\hline Pandanus & Pandan wangi & Pandanaceae & Pandanus amaryllifolius Roxb. & Herbs-spices & Leaf \\
\hline Pepper & Lada & Piperaceae & Piper nigrum L. & Herbs-spices & Seed \\
\hline
\end{tabular}




\begin{tabular}{|c|c|c|c|c|c|}
\hline Betel & Sirih & Piperaceae & Piper betle L. & Herbs-spices & Leaf \\
\hline Lemongrass & Serai & Poaceae & Cymbopogon citratus (DC.) Stapf & Herbs-spices & Leaf \\
\hline Rice & Burung naga & Poaceae & Oryza sativa $\mathrm{L}$. & Staple & Seed \\
\hline Rice & $\mathrm{C} 4$ & Poaceae & Oryza sativa L. & Staple & Seed \\
\hline Rice & Beras ketan & Poaceae & Oryza sativa $\mathrm{L}$. & Staple & Seed \\
\hline Rice & Ketan putih & Poaceae & Oryza sativa L. & Staple & Seed \\
\hline Rice & Menthik wangi & Poaceae & Oryza sativa $\mathrm{L}$. & Staple & Seed \\
\hline Rice & Beras merah & Poaceae & Oryza sativa L. & Staple & Seed \\
\hline Rice & Naga Mas & Poaceae & Oryza sativa $\mathrm{L}$. & Staple & Seed \\
\hline Rice & Pandan wangi & Poaceae & Oryza sativa L. & Staple & Seed \\
\hline Rice & $\begin{array}{l}\text { Super Premium } \\
\text { RMI }\end{array}$ & Poaceae & Oryza sativa $\mathrm{L}$. & Staple & Seed \\
\hline Corn & Jagung & Poaceae & Zea mays L. & Staple, vegetables & Fruit \\
\hline Apple & Apel & Rosaceae & Pyrus malus L. & Fruit & Fruit \\
\hline Red apple & Apel merah & Rosaceae & Malus domestica Borkh. & Fruit & Fruit \\
\hline Stayman apple & Apel Stayman & Rosaceae & Malus domestica Borkh. & Fruit & Fruit \\
\hline Strawberry & Strowberi & Rosaceae & $\begin{array}{l}\text { Fragaria ananassa (Duchesne ex Weston) } \\
\text { Duchesne ex Rozier }\end{array}$ & Fruit & Fruit \\
\hline Sweet orange & Jeruk manis & Rutaceae & Citrus sinensis (L.) Osbeck & Fruit & Fruit \\
\hline Pummelo & Pamelo & Rutaceae & Citrus maxima (Burm.) Merr. & Fruit & Fruit \\
\hline Tangerine & Jeruk keprok & Rutaceae & Citrus reticulata Blanco & Fruit & Fruit \\
\hline Santang orange & Jeruk santang & Rutaceae & Citrus sp. & Fruit & Fruit \\
\hline Key lime & Jeruk nipis & Rutaceae & Citrus medica f. aurantifolia (Christm.) M.Hiroe & Fruit & Fruit \\
\hline Kaffir lime & Jeruk purut & Rutaceae & Citrus hystrix DC. & Herbs-spices & Leaf \\
\hline Longan & Kelengkeng & Sapindaceae & Dimocarpus longan Lour. & Fruit & Fruit \\
\hline Rambutan & Rambutan & Sapindaceae & Nephelium lappaceum L. & Fruit & Fruit \\
\hline Manilkara & Sawo kecik & Sapotaceae & Manilkara kauki (L.) Dubard & Fruit & Fruit \\
\hline Manilkara & Sawo duren & Sapotaceae & Chrysopillum cainito L. & Fruit & Fruit \\
\hline Chili & Cabe & Solanaceae & Capsicum annuum L. & Vegetable & Fruit \\
\hline Red chilli & Cabe kriting merah & Solanaceae & Capsicum annuum L. & Vegetable & Fruit \\
\hline Green chili & Cabe kriting hijau & Solanaceae & Capsicum annuum L. & Vegetable & Fruit \\
\hline Green eggplant & Terong hijau & Solanaceae & Solanum melongena L. & Vegetable & Fruit \\
\hline Purple eggplant & Terong ungu & Solanaceae & Solanum melongena L. & Vegetable & Fruit \\
\hline Tomato & Tomat & Solanaceae & Solanum lycopersicum L. & Vegetable & Fruit \\
\hline Red grape & Anggur merah & Vitaceae & Vitis vinifera $\mathrm{L}$. & Fruit & Fruit \\
\hline Ginger & Jahe & Zingiberaceae & Zingiber officinale Roscoe & Herbs-spices & Rhizome \\
\hline Red ginger & Jahe merah & Zingiberaceae & Zingiber officinale var. rubrum & Herbs-spices & Rhizome \\
\hline Cardamom & Kapulaga & Zingiberaceae & Amomum compactum Sol. ex Maton & Herbs-spices & Seed \\
\hline Galangal & Lengkuas & Zingiberaceae & Alpinia galanga L. Willd & Herbs-spices & Rhizome \\
\hline Aromatic ginger & Kencur & Zingiberaceae & Kaempferia galanga L. & Herbs-spices & Rhizome \\
\hline Turmeric & Kunir & Zingiberaceae & Curcuma domestica Valeton & Herbs-spices & Rhizome \\
\hline Curcuma & Temu lawak & Zingiberaceae & Curcuma zanthorrhiza Roxb. & Herbs-spices & Rhizome \\
\hline Pink and blue ginger & Temu ireng & Zingiberaceae & Curcuma aeruginosa Roxb. & Herbs-spices & Rhizome \\
\hline White ginger & Temu putih & Zingiberaceae & Curcuma zedoaria (Christm.) Roscoe & Herbs-spices & Rhizome \\
\hline
\end{tabular}

\section{Herbs and spices}

Fabaceae. The most commonly traded plant was from the family Fabaceae, consisting of 13 species. Other studies in Indonesia also showed that Fabaceae was the most sold vegetable in vegetable markets in Bengkulu (Wiryono and Nurliana 2019) and Yogyakarta (Nurliana and Wiryono 2021). Likewise, two studies abroad also reported that Fabaceae was the most frequently sold family in the herbal market in Pakistan (Zahoor et al. 2021) and in the local market in Tanzania (Hilonga et al. 2019). Both studies showed the most popular usage of Fabaceae was to treat human ailments including rheumatism and urinary problems (Uzun and Koca 2020). In Ir Soekarno Market, Fabaceae was mostly sold as vegetables and the rest as herbs, 12 species, and spices, 1 species. Caesalpinia sappan was the only spices category from Fabaceae sold in Ir. Soekarno Market, which was used, in combination with other spices, as a traditional drink beverage from Yogyakarta, called 'wedang uwuh' (Pudjowati et al. 2021) and with sugar cube as traditional spicy drink from Sasak tribe, Lombok Island, named Ai'sepang (Sukenti et al. 2019).

Zingiberaceae. Zingiberaceae also dominated this market mainly because they are one of the most sought by customers. In this market, the genus Curcuma (locally known as temu) was the most commonly found commodity from Zingiberaceae family, for instance, $C$. domestica, $C$. zanthorrhiza, $C$. aeruginosa, and $C$. zedoaria. These plants have profound functions and are widely used by society as herbal medicines. Due to the high demand, Central Java 
has become the highest producer of turmeric, i.e., 42,400 tons/year (Salim et al. 2017). In seven local markets in Yogyakarta, Jalil et al. (2021) found that turmeric became the most frequently sold, which constituted $92.10 \%$ of the total rhizomes.

Ir. Soekarno Market's customers purchased Zingiberaceae commodities mainly for herbs and spices. A species of Zingiberaceae, Alpinia galanga, commonly found in this research area, is native to Java $(\mathrm{Wu}$ et al. 2021), which grows well in wet and shady habitats (Hanh et al. 2014). A. galanga is mainly used to create a unique flavor and seasoning food in Tamiang tribe, Aceh (Navia et al. 2020). In Kudus, Central Java, A. galanga is used to cure tinea versicolor (panu) as well as seasoning (Khusna 2019), while in Mt. Ungaran foothill, Central Java, A. galanga is used for treatment of headache and stomachache (Utami et al. 2019). Apart from their usage as spices in many cuisines, Zingiberaceae is also known for their function as the main ingredient of jamu (Indonesian traditional concoction made from various herbal products). Silalahi (2020) reported the usage of Kaempferia galanga as the major component of jamu in Central Java. Even though there is no clear evidence yet about the effectiveness and drawbacks of jamu consumption (Lim and Pranata 2020), the demand from the consumers due to the pandemic clearly caused the price increases of spices.

\section{Vegetables}

In terms of category, both vegetable and fruit sales made the highest proportion that accounted for $38 \%$ and $30 \%$ respectively, followed by spices and herbs at $21 \%$, while staple food only made up $11 \%$ (Figure 4). This finding is supported by Iskandar et al. (2018) study that the highest food crop commodity was vegetables. The number of vegetable species was 103 . This proves that each place has different commodities and quantities due to each region's economic, socio-cultural, and ecological factors. Vegetable and fruit diversity strongly correlates with ecological factors that make the product available in certain areas. Sarjono et al. (2019) mentioned that Central Java was one of the largest producers of both vegetables and fruits. Furthermore, Ir. Soekarno market is close to the Tawangmangu area, a mountainous agricultural region and many fruit and vegetable suppliers come from this place. Other neighboring villages also have different farming commodities offered to big sellers in this market. Central Java is also the biggest shallot producer in Indonesia according to Sholihah and Karsinah (2019). Thus, the high availability of those commodities makes buyers tend to purchase them. Kosaka et al. (2018) also said that food availability and diversity and accessibility became the main determinants for food consumption in society.

\section{Staple foods}

Most Indonesian people have a significantly high dependence on rice as the main source of carbohydrates (Nasikh et al. 2021). Even though the availability of rice substitutes is relatively high in Ir. Soekarno market, for instance, Ipomoea batatas, Manihot esculenta, and Zea mays, it cannot completely change society consumption behavior. Often, these rice substitutes were eaten as side dishes and desserts. The high availability of this alternative food showed the main contribution of the traditional market in strengthening national food security and helping the authorities promote food diversification (Saediman et al. 2019).

\section{Intraspecies variation}

Apart from variations of the staple food, Ir. Soekarno Market also has several intra-species variants of several species of edible plants and fruits. Besides rice, there are onions, bananas, and legumes (nuts).

\section{Rice}

People have their own preferences which affect the diversity of commodities that are traded in traditional markets. In Ir. Soekarno Market, 9 varieties of rice (Oryza sativa) have different qualities and prices (Table 2). The research by Muthayya et al. (2014) showed that before trading process, the rice was processed in rice mill for free and the miller get rice bran as an exchange. Rice sold in this market can be classified based on the rice grain's color, aroma, texture, and shape. Based on its quality, the rice can be categorized as superior and non-superior. Rice with superior quality includes C4, ketan putih, menthik wangi, and naga mas.

Meanwhile, rice with less superior quality includes beras merah, burung naga, beras ketan, pandan wangi, and super premium RMI. Almost all of those variations have excellent fragrances, except beras merah and burung naga. Some researchers mentioned that farmers are not really interested in planting pandan wangi because of some reasons mainly from lack of socialization from the local government and that the harvest cannot cover the initial price (Lisarini et al. 2018; Supyandi et al. 2019). By botanists, rice is grouped into two varieties: Oryza sativa japonica and Oryza sativa indica (Widjaja et al. 2014).

\section{Onions}

Onions as a commodity can be grouped into 4 variations, namely onion, shallot, spring onion, and garlic. The variations from one onion to another can be distinguished from their aroma, color, and morphology (Table 3). However, some traders cannot differentiate between onion and shallot only based on their shape and size. According to Risfaheri et al. (2019) flavor content measurement become the effective way to distinguish between those two varieties.

\section{Bananas}

The banana trading is considerably high because of the many plantations owned by local residents. Furthermore, variation of bananas can be grouped into pisang ambon, kapas, kapok, mas, raja, susu, and uli. The naming system from locals is usually based on their local knowledge inherited through generations. The variations from one banana to another can be detected by the taste, color, and morphological factors. Banana with the best quality is pisang raja because it has a delicious taste, and a large and long shape (Table 4). Moreover, it plays essential role in 
Javanese culture especially on special occasions, so commonly it has a higher price (Hapsari et al. 2017) than the other banana varieties, such as pisang kapok.

\section{Legumes}

In addition, there are also 9 variations of legumes, namely mungbean, peas, pea, black soybeans, red soybeans, cashews, long beans, and peanuts. Their color, taste and morphology can distinguish the variety of legumes. Mungbean, black soybeans, red soybeans, cashews, mungbean, and peanuts belong to superior quality, while pea (kacang kapri) and pea (kacang ercis) are considered not superior. Interestingly, all of the variations have delicious tastes (Table 5). This pleasant taste becomes one of the supporting factors for buyers to purchase these items. Similarly, the study of SminglakKrajewska et al. (2020) in Poland found that flavor and price are the main things of consumers' decision to buy legumes as substitutes for meat-based food.

Table 2. Variations of rice traded in Ir. Soekarno Market, Sukoharjo, Indonesia

\begin{tabular}{llllll}
\hline Variation & Quality & Smell & Texture & Rice color & Rice grain morphology \\
\hline Beras merah & Less superior & It doesn't smell good & Sticky & Red & Small slim size \\
Burung naga & Less superior & Not Fragrant & Not sticky & Yellow & Medium size \\
C4 & Superior & Fragrant & Not sticky & Clean yellow & Medium size \\
Beras ketan & Less superior & Fragrant & Sticky & Black & Medium size, slim \\
Ketan putih & Superior & Fragrant & Sticky & Clean yellow & Medium size, slim \\
Menthik wangi & Superior & Fragrant & Not sticky & Clean yellow & Short round size \\
Naga Mas & Superior & Fragrant & Not sticky & Clean yellow & Long slender size \\
Pandan wangi & Less superior & Fragrant & Not sticky & Yellow & Medium size \\
Super Premium RMI & Less superior & Fragrant & Not sticky & Clean yellow & Slim long size \\
\hline
\end{tabular}

Table 3. Variations of onions traded in Ir. Soekarno Market, Sukoharjo, Indonesia

\begin{tabular}{llll}
\hline Variation & Smell and quality & Color & Morphology \\
\hline Onion & The aroma is fragrant, the slices make eyes stinging & $\begin{array}{l}\text { The outside is brown } \\
\text { inside white }\end{array}$ & Large round shape and thick fleshy \\
$\begin{array}{l}\text { Shallot } \\
\text { Spring onion }\end{array}$ & $\begin{array}{l}\text { The aroma is fragrant, the slices make eyes stinging } \\
\text { The aroma is fragrant, the slices make the eyes } \\
\text { slightly watery } \\
\text { The aroma is fragrant, the slices do not make eyes } \\
\text { watery }\end{array}$ & $\begin{array}{l}\text { Green and white seeds } \\
\text { Garlic }\end{array}$ & $\begin{array}{l}\text { Round with blunt tip wraps 2-3 seeds } \\
\text { Flat long but have no tubers }\end{array}$ \\
\hline
\end{tabular}

Table 4. Variations of bananas traded at Ir. Soekarno Market, Sukoharjo, Indonesia

\begin{tabular}{lll}
\hline Variation & Taste and quality & Color \\
\hline Pisang ambon & Delicious and superior, slightly hard texture & Greenish-yellow \\
Pisang kapas & Fragrant and not superior, slightly soft texture & Dirty light yellow \\
Pisang kapok & Delicious and superior, slightly hard texture & Dirty dark yellow \\
Pisang mas & Somewhat good and not superior, slightly soft texture & Clean bright yellow \\
Pisang raja & Delicious and superior, soft texture & A little dark yellow $\quad$ Medium and wide sizes $\quad$ Clean bright yellow $\quad$ Large size and long Small and short in size \\
Pisang susu & Delicious and superior, soft texture & A little dark yellow \\
Pisang uli & Not tasty and not superior, a little tough & Medium size \\
\hline
\end{tabular}

Table 5. Variations of legume traded in Ir. Soekarno Market, Sukoharjo, Indonesia

\begin{tabular}{llll}
\hline Variation & Taste and quality & Color & Morphology \\
\hline String bean & Delicious and not superior & Green & Slightly wide, shorter \\
Mungbean & Delicious and superior & Dark green & Round \\
Pea & Delicious and not superior & Light green & Round \\
Black soybeans & Delicious and superior & Dark black & Round \\
Red soybeans & Delicious and superior & Dark red & Round \\
Cashew nut & Delicious and superior & Light yellow & Shaped like the letter C \\
Long beans & Delicious and superior & Green & Slim, long \\
Peas & Delicious and not superior & Green & Round \\
Peanuts & Delicious and superior & Sorrel & Oval round \\
\hline
\end{tabular}




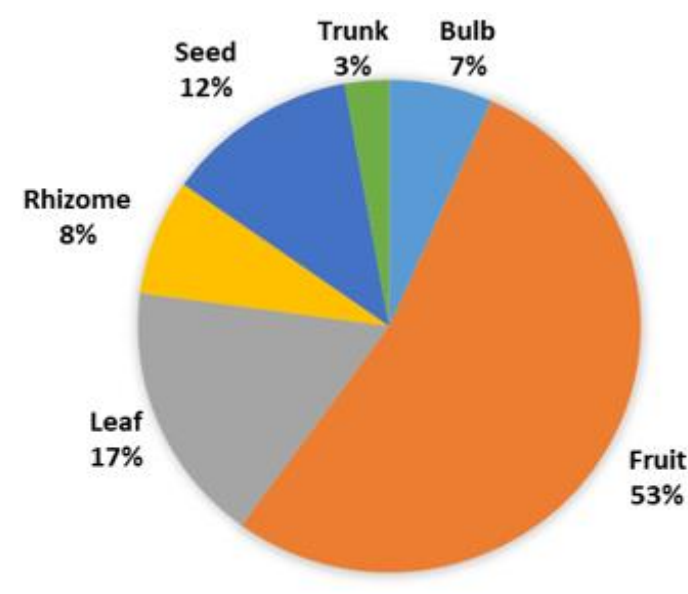

Figure 5. Parts of plants that can be consumed and traded in Ir. Soekarno Market

\section{Plant parts}

There were six parts of plants commonly used as food commodities in Ir. Soekarno Market, namely fruit, seed, leaf, rhizome, tuber (bulb), and bark (trunk) (Table 1, Figure 5). Most food plants were sold in the form of fruit, i.e., 56 out of 105 species (53\%), followed by leaves 18 species, seed 13 species, rhizomes 8 species, tuber 7 species, and bark 3 species. Fabaceae, Solanaceae, and Musaceae dominated the fruit commodities in Ir. Soekarno Market.

\section{Fruits}

This market traded various kind of oranges, the most favorite one was Pummelo that has been widely cultivated in Magetan District, East Java. Some of pummelo farmers from Magetan sold their harvests in this market. Orange can be consumed as fresh fruit or as ingredient of food or beverage. Both Citrus hystrix and Citrus aurantifolia are commonly used to add unique flavor to food and drink beverages (Enejoh et al. 2015).

\section{Leaves}

Seventeen percent of plant commodities were sold in the form of leaf, which was dominated by the family Brassicaceae. Mostly, they were included in vegetable groups, such as leek (Allium ampeloprasum), broccoli (Brassica oleracea var. italic), leeks (Allium fistulosum), celery (Apium graveolens), kale (Brassica oleracea var. sabellica), cauliflower (Brassica oleracea var. botrytis), wild cosmos (Cosmos caudatus), cabbage (Brassica oleracea var. capitata.), pandanus (Pandanus amaryllifolius), and green mustard (Brassica juncea L).

\section{Rhizomes and seeds}

This research found that there is a high diversity of varieties within a plant species in Ir. Soekarno Market. Rhizome constituted $8 \%$ of the food plant in this study, and was totally from the family Zingiberaceae. Amomum compactum was the only exception of Zingiberaceae that was generally sold as seed (Table 1). A. compactum is endemic to West Java ( $\operatorname{Lim} 2021$ ) and is known as kapulaga in Javanese and has been used for many purposes, mainly for spice and herbal medicine. Seed and grain selling alone composed more than $10 \%$ of the total products, mainly came from Poaceae as staple food.

\section{Tubers}

Carbohydrate staple food source can also be obtained from tuber. In this market, the tuber availability was $7 \%$ including Daucus carota, Ipomoea batatas, Manihot esculenta, and Solanum tuberosum (Table 1). However, the sellers mostly sold tuber from Alliaceae mainly used as food ingredient, spices and vegetables.

\section{Barks}

Lastly, bark was the least sold part of plants (3\%), composed of Fabaceae and Lauraceae, indicating that bark was not commonly sold as food in community, unlike in the Philippines where the utilization of trunk/bark ranked second after leaf (Pizon et al. 2016).

\section{Traditional markets and biodiversity}

Ir. Soekarno Market offered diverse products, especially in food crop commodities, including carbohydrates, spices, vegetables, and fruits. The food crop commodities traded in this market were mostly supplied from the Tawangmangu area, Karanganyar, Central Java, Indonesia. Various vegetables and fruits became the major goods from this rural area, for instance, carrots, cabbage, and strawberries (Sarjono et al. 2019). Traditional markets provide a more diverse community, both as traders and consumers than modern markets. Along with the increasing demand for various agricultural products, there is also an increase in the variety of agricultural plant products offered in traditional markets. Vegetable commodity which is usually traded in Ir. Soekarno Market has high diversity due to the high demand from the customers.

The purpose of the local market is to meet the needs of buyers and provide job opportunities and strengthen social interaction. This also leads to reducing poverty and contributing to national economy (Agboola et al. 2018). Montalbano et al. (2018) mentioned a profound correlation between farmers' food security and their involvement in the market chain. Thus, urban traditional markets play an essential role in trading the diverse local agricultural products and providing food for the locals (Vlkova et al. 2015). Another benefit of traditional market is to retain the local knowledge about herbal medicine (Salim et al. 2019). One clear example is that jamu trade in Ir. Soekarno Market helps to give knowledge about this traditional drink to their customers that might be young people. Subsequently, this local wisdom can be transferred through generations.

In this study, the commodities traded were mostly local products. Ir. Soekarno Market has a role in offering a variety of edible food crops produced by farmers from the surrounding areas. In addition, this market also plays a considerable part in preserving biodiversity, especially 
edible plants. If the market demand increases, the initiative of the vegetable farmers will also increase to provide the demands, so this will prevent biological extinction. This includes the actions of cultivating and conserving biodiversity through agricultural land. Similarly, Arellanes et al. (2013) argued that people tend to treat well plant species with an economic value if the plants are endangered. However, over-selling and over-consumption without preventive action such as regulation and cultivation will lead to species extinction.

To conclude, Ir. Soekarno Market has an important role as a place for trading activities between sellers and buyers in the economic sector that offers a variety of food plants, consisting of 105 species from 28 families, sold in the form of fruit, seeds or grain, leaf, rhizome, tuber, and stem. The variety of staple products helps to increase food diversification and food security and to conserve plant diversity.

\section{ACKNOWLEDGEMENTS}

The authors would like to thank all participants in this research, i.e. sellers, customers, and management of Ir. Sukarno Market, Sukoharjo, Indonesia, as well as the reviewers for their valuable comments.

\section{REFERENCES}

Agboola OP, Azizul MF, Rasidi MH, Said I. 2018. The cultural sustainability of traditional marketplace in Africa: A new research agenda. J Rural Stud 62: 87-106. DOI: 10.1016/j.jrurstud.2018.07.001

Aliyah I. 2017. Pemahaman konseptual pasar tradisional di perkotaan. Cakra Wisata 18 (2): 1-16. [Indonesian]

Aminursita O, Abdullah MF. 2018. Identification of market structure in the ceramic industry in Malang City. J Econ 2 (3): 409-418.

Aprilianawati AT, Herawati NR. 2018. Perlawanan pedagang pasca revitalisasi: Studi penelitian di pasar Ir. Soekarno, Kabupaten Sukoharjo. J Pol Govern Stud 7 (3): 161-170. [Indonesian]

Ar Rosyidi HM, Adhi S, Astrika L. 2016. Analisis implementas revitalisasi pasar tradisional Ir. Soekarno Kabupaten Sukoharjo dalam rangka meningkatkan kualitas pelayanan. J Pol Govern Stud 5 (4): 110. [Indonesian]

Arellames Y, Casas A, Arellanes A, Vega E, Blancas J, Vallejo M, Torres I, Rangel-Landa S, Moreno AI, Solis L, Perez-Negron E. 2013. Influence of traditional markets on plant management in the Tehuacán Valley. J Ethnobiol Ethnomed 9, 38. DOI: 10.1186/1746-4269-9-38

Arianty N. 2013. Analysis of differences between modern and traditional markets in terms of layout strategy and service quality to improve traditional market bargaining position. J Manag Business 13 (1): 1829.

Backer CA, Bakhuizen van den Brink RC. 1963. Flora of Java (Spermatophytes only). Vol. 1. Wolter-Noordhoff N.V., Groningen.

Backer CA, Bakhuizen van den Brink RC. 1965. Flora of Java (Spermatophytes only). Vol. 2. Wolter-Noordhoff N.V., Groningen.

Backer CA, Bakhuizen van den Brink RC. 1968. Flora of Java (Spermatophytes only). Vol. 3. Wolter-Noordhoff N.V., Groningen.

Cadilhon JJ, Moustier P, Poole ND, Tam PTG, Fearne AP. 2006 Traditional vs. modern food systems? Insights from vegetable supply chains to Ho Chi Minh City (Vietnam). Develop Policy Rev 24 (1): 31-49. DOI: 10.1111/j.1467-7679.2006.00312.x

de Guzman CC, Siemonsma JS (eds). 1999. Plant resources of South-East Asia. vol. 13. Spices. Backhuys, Leiden.

de Padua LS, Bunyapraphatsara N, Lemmens RHMJ (eds.). 1999. Plant Resources of South-East Asia (PROSEA). Vol. 12-1. Medicinal and Poisonous Plants 1. Backhuys, Leiden, Netherlands.
Ela ZK, Laoh OEH, Mandei JR. 2016. Determinants of agricultural commodity consumer choices of shopping at traditional and modern markets in Manado City. ASE 12 (1): 77-90. DOI: 10.35791/Agrsosek.12.1.2016.11401

Ellen RF, Hermien LS. 2012. A comparative study of the socio-ecological concomitant of cassava (Manihot esculenta Crantz) diversity, local knowledge, and management in Eastern Indonesia. Ethnobot Res Appl 10: 15-35. DOI: 10.17348/Era.10.0.015-035

Enejoh OS, Ogunyemi IO, Bala MS, Oruene IS, Suleiman MM, Ambali SF. 2019. Ethnomedical importance of Citrus aurantifolia (Christm) Swingle. Pharm Innov J 4 (8): 1-6.

Grubben G.J.H, Partohardjono S (eds). 1996. Plant resources of SouthEast Asia. vol. 10. Cereals. ed. by Backhuys, Leiden

Hanh NP, Binh NQ, Adhikari BS. 2014. Distribution of Alpinia (Zingiberaceae) and their use pattern in Vietnam. J Biodivers Endanger Species 2: 121. DOI: 10.4172/2332-2543.1000121

Hapsari L, Fauziah, Trimanto. 2019. Morphology and molecular identification of local cultivars of pisang raja (Musa spp.) from Yogyakarta, Central Java and East Java, Indonesia. Proceeding of The International Conference on Tropical Plant Conservation And Utilization, 18-20 May 2017.

Hilonga S, Otieno JN, Ghorbani A, Pereus D, Kocyan A, De Boer H. 2019. Trade of wild-harvested medicinal plant species in local markets of Tanzania and its implications for conservation. South Afr J Bot 122: 214-224. DOI: 10.1016/J.Sajb.2018.08.012

Indrawati T, Yovita I. 2014. Analysis of sources of capital for traditional market traders in Pekanbaru City. J Econo 22 (1): 1 - 8.

Iskandar BS, Iskandar J, Irawan B, Partasasmita R. 2018. Traditional markets and diversity of edible plant tranding: Case study in Ujung Berung Bandung West Java Indonesia. Biodiversitas 19 (2): 437-452. DOI: 10.13057/biodiv/D190211

Jalil M, Purwantoro A, Baryono BS, Kurniawan FY, Purnomo. 2021. The commodity of Curcuma spp. sold in the traditional markets of Yogyakarta. IOP Conf Ser: Earth Environ Sci 762: 012039. DOI: 10.1088/1755-1315/762/1/012039

Jeong SK, Ban YU, 2020. Spatial configurations for the revitalization of a traditional market: The case of Yukgeori Market in Cheongju, South Korea. Sustainability 12 (7): 2937. DOI: 10.3390/su12072937

Kharisma E. 2014. Agricultural commodity market chain and its impact on agricultural commodity trading activities in Projo Market. J Reg Environ 2 (1): 25-42.

Khusna UN. 2019. Studi etnobotani pemanfaatan Suku Zingiberaceae di Desa Colo, Kecamatan Dawe, Kabupaten Kudus, Provinsi Jawa Tengah. [Hon. Thesis]. Fakultas Sains dan Teknologi, Universitas Islam Negeri Walisongo, Semarang. [Indonesian]

Kosaka S, Suda K, Gunawan B, Raksanagara A, Watanabe C, Umezaki M. 2019. Urban-rural difference in the determinants of dietary and energy intake patterns: A case study in West Java, Indonesia. Plos ONE 13 (5): E0197626. DOI: 10.1371/Journal.Pone.0197626

Lemmens RHMJ, Bunyapraphatsara N (eds.). 2003. Plant Resources of South-East Asia (PROSEA). Vol. 12-1. Medicinal and Poisonous Plants 1. Backhuys, Leiden, Netherlands.

Lemmens RHMJ, Wulijarni-Soetjipto N (eds.). 1991. Plant Resources of South-East Asia (PROSEA). Vol. 3. Dye and Tannin-Producing Plants. Pudoc, Wageningen, Netherlands.

Lim MA, Pranata R. 2020. The insidious threat of jamu and unregulated traditional medicines in the COVID-19 era. Diabetes Metabolic Syndrome: Clin Res Rev 14 (5): 895. DOI: 10.1016/J.Dsx.2020.06.022

Lim TK. 2012. Amomum compactum. Edible Medicinal and NonMedicinal Plants. Springer, Dordrecht. DOI: 10.1007/978-94-0075653-3_46

Lima-Filho DO, Hokama AS, Spanhol CP. 2009. Behavior of the vegetable crops section in three types of food retail stores in Campo Grande, Brazil. Hort Bras 27: 086-090. DOI: 10.1590/S010205362009000100017

Lisarini E, Yusuf E, Sutina. 2018. The effect of quality, communication and outputs of marketing channel of Cianjur Pandanwangi Rice on consumer trust in Java West marketing area. Indones $\mathrm{J}$ Business Entrepreneurship 4 (2): 109-117. DOI: 0.17358/IJBE.4.2.109

Majiid RIS, Sutrisno J. Barokah U. 2020. Measuring the satisfaction levels of customers of fresh vegetables towards the marketing mix in traditional markets in Sukoharjo District, Indonesia. Caraka Tani: J Sustain Agric 35 (1): 117-125. 10.20961/carakatani.v35i1.34476 
Malano H. 2011. Save Traditional Markets A Portrait of The Small People Economy. PT Gramedia Pustaka, Jakarta.

Montalbano P, Pietrelli R, Salvatici L. 2018. Participation in the market chain and food security: The case of the Ugandan maize farmers. Food Pol 76, 81-98. DOI: 10.1016/j.foodpol.2018.03.008Muthayya S, Sugimoto JD, Montgomery S, Maberly GF. 2014. an overview of global rice production, supply, trade, and consumption. Ann NY Acad Sci 134 (1): 7-14. DOI: 10.1111/Nyas. 12540

Nasikh, Kamaludin M, Narmaditya BS, Wibowo A, Febrianto. 2021. Agricultural land resource allocation to develop food crop commodities: Lesson from Indonesia. Heliyon 7 (7): E07520. DOI: 10.1016/J.Heliyon.2021.E07520

Naufal M, Salam M, Khatimah H. 2021. Analyzing the amount of Banana Kepok marketing margin. IOP Conf Ser: Earth Environ Sci 681: 012111. DOI: $10.1088 / 1755-1315 / 681 / 1 / 012111$

Navia ZI, Audira D, Afifah N, Turnip K, Nuraini, Suwardi AB. 2020. Ethnobotanical investigation of spice and condiment plants used by the Taming Tribe in Aceh, Indonesia. 21 (10): 4467-4473. DOI: 10.13057/Biodiv/D211001

Nurliana S, Wiryono. 2021. Keragaman dan komposisi jenis sayur di pasar tradisional dan supermarket di Yogyakarta. Jurnal Naturalis 10 (1): 24-30. [Indonesian]

Pizon JRL, Nuneza OM, Uy MM, Senarath WTPSK. Ethnobotany of medicinal plants used by the Subanen Tribe of Lapuyan, Zamboanga Del Sur. Bull Env Pharmacol Life Sci 5 (5): 53-67.

Pudjowati J, Abdurrahman T, Pratiwi EP, Baqi RN, Syafitri AK. 2021. Community empowerment through homegrown medicinal plants and the "wedang uwuh" herbal beverage cultivation in Seketi Hamlet. J Commun Pract Soc Welfare 1 (2): 1-15. DOI 10.33479/Jacips.2021.1.2.1-15

Rahadi RA. 2011. Factors related to repeat consumption behaviour: A case study in traditional market in Bandung and surrounding region. Procedia-Soc Behav Sci 36: 529-539. DOI: 10.1016/j.sbspro.2012.03.058

Risfaheri, Jamal IB, Sukasih E, Sulaeman AA, Setyadjit. 2019. Substitution of shallot using small size onion: Result of an introductory mini-survey on quality in the market. IOP Conf Ser: Earth Environ Sci 309: 012008. DOI: 10.1088/1755 1315/309/1/012008

Rusham. 2016. Analysis of the impact of modern market growth on the existence of traditional markets in Bekasi District. Optimal Manag Econ Entrepreneur Sci J 10 (2): 153-166.

Saediman H, Siti A, Zani M, Limi MA, Yusria WO. 2019. Food security status of households in a cassava-growing village in Southeas Sulawesi, Indonesia. J Agric Extension 23 (1): 199-209. DOI 10.4314/Jae.V23i1.17

Sahban H, Perwira I. 2018. Empowerment of traders and traditional market potential development in Indonesia. Int J Innov Sci Res Technol 3 (1): 428-436. DOI: 10.31219/osf.io/38f59

Salim MA, Ranjitkar S, Hart R, Khan T, Ali S, Kiran C, Parveen A, Batool Z, bano S, Xu J. 2019. Regional trade of medicinal plants has facilitated the retention of traditional knowledge: case study in GilgitBaltistan Pakistan. J Ethnobiol Ethnomed 15,6. DOI 10.1186/s13002-018-0281-0

Salim Z, Munadi E, Nugroho R A, Ningsih E A, Paryadi D, Utama R, Saputri AS, Andrian N, Faradila F. 2017 Info Komoditi Tanaman Obat, $1^{\text {st }}$ Edition. Badan Pengkajian dan Pengembangan Perdagangan Kementerian Perdagangan Republik Indonesia, Jakarta, Indonesia. [Indonesian]

Sarjono, Haryadi, Jadi BN, Handoko BL. 2019. Supply chain for potato products in Tawangmangu, Central Java, Indonesia. Proceedings of The 2019 10th International Conference on E-Business, Management And Economics. DOI: 10.1145/3345035.3345077

Septiari ED, Kusuma GH. 2016. Understanding the perception of millennial generation toward traditional market (A study in Yogyakarta). Rev Integr Business Econ Res 5 (1): 30-43.
Sholihah S, Karsinah. 2019. Integration of Central, East, West Java and Jakartas shallot market. Econ Dev Anal J 8 (4): 252-266. DOI: 10.15294/Edaj.V8i4.35276

Siemonsma JS, Piluek K (eds). 1991. Plant Resources of South-East Asia (PROSEA). Vol. 8. Vegetables. Pudoc, Wageningen, Netherlands.

Silalahi M. 2020. Kaempferia galanga L. Zingiberaceae. Ethnobot Mount Regions Southeast Asia 1-7. DOI: 10.1007/978-3-030-14116-5_87-1

Sminglak-Krajewska M, Wojciechowska-Solis J, Viti D. 2020. Consumers' purchasing intentions on the legume market as evidence of sustainable behavior. Agriculture 10 (424): 1-20. DOI: 10.3390/Agriculture10100424

Suhud U, Allan M, Wibowo SF, Sabrina E, Willson G. 2019. Measuring customer satisfaction of a café and coffee shop colony at a traditional market. J Foodservice Business Res 23 (1): 1-17. DOI: $10.1080 / 15378020.2019 .1686897$

Sukenti K, Hakim L, Indriyani S, Purwanto. 2019. Ethnobotany of Sasak traditional beverages as functional foods. Indian J Tradit Knowledge 18 (4): 775-780.

Supyandi D, Sukayat Y, Charina A. 2019. Sustainable local rice development (A case of Pandanwangi rice development in Cianjur, Indonesia). IOP Conf Ser: Earth Environ Sci 306: 012034. DOI: $10.1088 / 1755-1315 / 306 / 1 / 012034$

Susanto RY 2018. The potential of Blimbing traditional market for communities around Lowokwaru Sub-district, Malang City. J Manag Sci Account 6 (2): 39-47.

Susilowati KDS. 2014. The impacts of modern market to traditional traders (A case in Malang City - Indonesia). Int J Tech Res Appl 2 (8): 38-44.

Syarifuddin D. 2018. Traditional markets in the perspective of the value of tourism attraction studies on the Monju morning market in Bandung City. J Resort Leisure Manag 15 (1): 19-32.

Utami NR, Rahayuningsih M, Abdullah M, Haka FH. 2019. Etnobotani tanaman obat masyarakat sekitar di Gunung Ungaran, Jawa Tengah. Pros Sem Nas Masy Biodiv Indon 5: 205-208. DOI: 10.13057/psnmbi/m050210. [Indonesian]

Uzun SP, Koca C. 2020. Ethnobotanical survey of medicinal plants traded in herbal markets of Kahramanmaras. Plant Divers 42: 443-454. DOI: 10.1016/J.Pld.2020.12.003

van der Vossen HAM, Umali BE (eds.). 2001. Plant resources of SouthEast Asia. vol. 14. Vegetable oils and fats. Backhuys, Leiden.

van Valkenburg JLCH, Bunyapraphatsara N (eds.). 2002. Plant Resources of South-East Asia (PROSEA). Vol. 12-2. Medicinal and Poisonous Plants 2. PROSEA Foundation, Bogor.

Verheij EWM, Coronel RE (eds.). 1991. Plant Resources of South-East Asia (PROSEA). Vol. 2. Edible Fruits and Nuts. Pudoc, Wageningen, Netherlands.

Vlkova M, Verner V, Kandakov A, Polesny Z, Karabaev N, Pawera L, Nadvornikova I, Banout J. 2015. Edible plants sold on marginal rural markets in Fergana Valley, southern Kyrgyzstan. Bulg J Agric Sci 21: 243-250

Widjaja EA, Rahayuningsih Y, Rahajoe JS, Ubaidillah R, Maryanto I, Waluyo EB, Semiadi G. 2014. Recent Indonesian Biodiversity 2014. The Indonesian Institute of Sciences (LIPI), Jakarta [Indonesian]

Wiryono, Nurliana S. 2019. Dominansi jenis-jenis tanaman sayur introduksi di pasar sayuran Kota Bengkulu. Life Sci 8 (2): 181-191. [Indonesian]

Wu M, Guo P, Tsui SW, Chen H, Zhao Z. 2012. An ethnobotanical survey of medicinal spices used in Chinese hotspots. Food Res Int 48: 226232. DOI: 10.1016/J.Foodres.2012.03.010

Yurlisa K, Maghfoer MD, Aini N, Sumiya W, Permanasari PN. 2017. Survey dan pendokumentasian sayuran lokal di pasar tradisional Kabupaten dan Kota Kediri, Jawa Timur. Jurnal Biodjati 2 (1): 52-63. DOI: 10.15575/Biodjati.V2i1.1287. [Indonesian]

Zahoor M, Yousaf Z, Yasin H, Shinwari ZK, Haroon M, Saleh N, Younas A, Aftab A, Shamsheer B, Qamar NR, Rashid M. 2021. Ethnobotanicals and commercial trends of herbal markets in Punjab, Pakistan. J Herb Med 26: 100425. DOI: 10.1016/J.Hermed.2021.100425. 